\title{
Leisure Organization Models of Young People in the North Mexican Border
}

\author{
Aida Yarira Reyes Escalante, Carlos Alberto Ochoa Ortiz Zezzati, \\ Edith Vera Bustillos, Alejandra Peña Escarcega \\ Universidad Autónoma de Ciudad Juárez (UACJ), \\ Ciudad Juárez, Chihuahua, Mexico \\ aida.reyes@uacj.mx
}

\begin{abstract}
Throughout an exploratory research design, we approach the study of youth organization in fulfilling leisure as an essential part of everyday life. We use data mining as the technique to drawing conclusions from our vast amount of data, upon extrapolating patterns and associating dependently linked variables and attributes. The structure of this paper is organized by the perspective of youth as a category of study, and conceptualization of human needs to understand the implications of these at the spare time. The organization is approached as a group of people related to systematic arrangement of social relations that give meaning to ideas, and values shared. The analysis is accomplished through data obtained from 300 participants aged 15 to 29, that shed light about categories of youth organization as an articulator of the social coexistence: demographics; preferences by age, gender, type, and frequencies of activities; spending; networks and the before and after-party activities, which counts the strategies they adopt for leisure, in the midst of a complex society in Ciudad Juárez, México. The leisure organizational model is constructed by elements related to various attributes into discernable categories, which can use to draw further conclusions about the theme approached.
\end{abstract}

Keywords: youth organization; youth and leisure; spare time; data mining; social construction.

\section{$1 \quad$ Human Needs in Spare Time and Leisure}

From a positivist perspective, it is considered that human needs have not been a central theme for the economic development theory. While Marx only addressed the mainstream in the economy of the twentieth century, human needs were supported in the anthropology of behavioral roots that offered utilitarianism and marginality, but only addressing consumer preferences [1]. The theme of human needs became an exclusive category of studies on poverty from an economistic point of view [2]. Thus, is important to consider the different disciplinary perspectives on human needs otherwise. In doing so, there is an important chronology of the definition of needs from different disciplines [3], which reveals a gap between a desired state of the person into the motivational state that arises of varying intensity, and a subjective need that can be derived from an action to correct determined situation: From Psychology, the need is the linked condition to the experience or deficiency associated with the effort aimed at suppressing the absence 
or scarcity, whose scope and complexity can be variable. While for the field of Education, human needs are link to the planning and educational research: improving, changing, preventing or solving problems of schooling. Regarding the scope of social policies, the needs are associated to the development of the welfare state as a criterion for access to the different dimensions of social protection, public health, and sustainability.

From all the different disciplinary perspectives mentioned above, we highlight the contributions from Psychology to the understanding of human needs, its classification, motivation, and impulses in the satisfaction of these. On the one hand, Maslow [4] exhibited his work in the theory of human motivation, formulating a hierarchy and arguing that as the basic needs (physiological needs) are met, people develop higher needs and desires. On the other hand, McDougall (1971-1938) was one of the first proponents about that intentionality and goal-seeking is what characterized more to human behavior and these depended on different components: cognitive, conative, and affective [6].

The influence of Psychology led globally in the early fifties. Particularly, in the United States was developed important studies of human motivation. For instance, Atkinson Van Nostrand presented a method for evaluating the human reasons (mobile) by analyzing the content of thematic stories and samples of imaginative thinking; concluding that meeting human needs was reduced to the urgency of accumulation, owning goods and services even regardless of its usefulness, emphasizing that the only real need is money [5].

Nevertheless, Doyal and Gough [6], argue that human needs are socially constructed, but also universal. They rejected the aspirations from particular preferences of individuals, instead, their cultural environment can be considered as a need, suggesting a distinction between basic needs and intermediate needs. While Max-Neef, Elizalde and Hopenhayn [7], defined human needs as an interrelated, and interactive system with no hierarchies or priorities between them, but recognizing the presence of a threshold below which the feeling of severe deprivation is recorded.

Related to one of the most important approaches in this study, we considered the perspective from Carosio [8], who states that the expansion and acceleration of consumption as the twentieth-century phenomenon, is part of the behavior to meet human needs that serves and articulates the relations of social coexistence of the consumer society. From a more technical perspective, Locke and Latham [9], incorporate the concept of motivation for studying human needs, choices, and preferences, referring to the existence of both internal factors driving the action, and external factors that can operate as a stimulus, influencing: direction (choice), intensity (effort), and duration (persistence).

\section{Leisure: Between Spare Time, Recreation, Amusement or Entertainment}

According to the Oxford Dictionary [10] "leisure" is the time when one is not working or occupied; free time. That implies the cessation of occupations for carrying out a recreational activity that becomes an essential part of everyday life. However, it is usually assumed that spare time or leisure is waste of time for not performing a productive 
task. Historically, leisure was associated with the upper classes of society, while the other population had no chance on enjoyment because they had to work for livelihood. Based on the perspective from Cicero about "leisure" (otium), in his speech, Pro Sestio, points out its relevance such as "a time to rest the body and recreation of the spirit necessary to tackle the task." In the Roman society, especially in big cities, there was a large focus on entertainment [11].

Throughout the International Worker's Association (ATI), the fight for the eight hours of labor was declared in the Congress in Geneva, August 1866, demanding that the legal limitation of the working days was a dignified precondition for the improvement and the same emancipation of the working class [12]. Subsequently, in developed societies of the mid-twentieth century, leisure was occupying an important stance in the everyday life of people since the increasing of life expectancy, quality of living conditions, educational level, among other elements. Thus, recreation and leisure previously reserved for a minority become more accepted in large social groups [13].

In addition, we identified other useful contributions analyzing the concept of leisure, such as those from Bock [14], who argue that within the theory of learning and spare time, presuppose decisions and behaviors from people, as a result of their previous experiences by successful repetition of pleasant stimuli, as those who are critical in determining the consumer or buying behavior. Moreover, Nuviala, Ruíz and Garcia [15], define leisure as "... period of time not subject to needs or obligations" (p.13). Meaning that the period of time can be occupied as well in the practice of any kind of activity in the school, home, work or family, which implies not only to have a spare time full of activities, but feeling free of doing or enjoying such activities. Then, leisure can be defined in simple words: the length of time used for activities in which the person has a time of enjoyment and satisfaction. Hence, an overlapping between the concepts of spare time and leisure arises.

Likewise, Munne and Codina [16], refers to spare time as the period of time to do some leisure activity, including the space remaining to do something that person can practice for pleasure after concluding obligatory activities, either fun or tedious. Thus, spare time is simply the length of time dedicated to activities that are made out by simple pleasure and are made without obligation. Similarly, Rodriguez and Agulló [17], argue that leisure is performed in spare time made up for activities and practices that are freely chosen according to the preferences of each individual to meet personal needs, which purpose is relaxation, entertainment, and enhancing of human development: physical, emotional, and cognitive.

In conclusion, leisure also articulates the social life because individuals can build relationships, and interests for enjoyment of recreation [8]. Thus, we recall in this study the relevance of youth organization for leisure as a social construction. In the following section, youth is described as a category of analysis in relation to their context.

\section{$3 \quad$ Leisure Venues}

Leisure activities have been classified into three major categories: type, nature, and structure. There are different types of entertainment, whether by water, land, or air, and can be performed individually or by group. The places where recreational activities can 
be carried out, they tend to be private, public, monitored, and controlled. Some entertainment or recreational activities usually depend on the geography, climate, resources, and culture that can be classified as follows [17]: Outdoor recreational activities, which can be on land, water, and air; activities for entertainment: sports, artistic, and cultural; cultural activities: Artistic activities, arts and crafts, symposia, lectures, oratories, and debates; events or shows: visits to artistic, cultural, historical, social, and sports shows; family activities: birthday parties, XV years, weddings, christenings, family gatherings, meetings, and conventions; games: board games, video games, and all kind of electronic games; specialized activities: communication, motorized, mental, and multiple activities for sensory disabilities; others: visual activities, hobbies, reading, and relaxation.

\section{$4 \quad$ Youth as a Social Group}

Youth as a social phenomenon emerged differentiated in Western society from the eighteenth and nineteenth centuries, a historical product that comes from the bourgeois revolutions, and development of capitalism [18]. Hence, youth as social group did not exist before. In a broader perspective, youth is considered as a stage of life mediating between biological and social maturity, and become identified as a social layer that should enjoy of certain privileges but from a period of permissiveness [19].

Contemporary contributions of literature have categorized the stages of the human life into four general stages: childhood, youth, adulthood, and elderly. At the stage of youth, it has several physical, psychological, and social changes that could involve major problems related to identity, confusion, among others issues. Although it is recognized that there are ambiguities in determining the juvenile stage, as defined by the United Nations, UN, youth involves those aged between 15 and 24 years old. While the United Nations Educational, Scientific and Cultural Organization, UNESCO (2016) [20], declares that youth is a heterogeneous group in constant evolution, and the experience of being young varies widely among countries, regions, and localities. However, for other institutions, the juvenile stage involves a combination of the biological and relative social maturity, from the adolescence throughout the independence from family, the autonomy that would define the adult status [21].

In general, youth is spent in the realm of the family. Leaving the family' home and gaining economic independence, make basic milestones for an autonomy that increases thru the traditional establishment with a stable partner, and procreation of the first child. Thus, youth is a stage in which usually responsibilities are more prominent and important than those in childhood, with more complex challenges as being prepared to reach the adult stage. Although, for Masjoan, Planas \& Casal [22], there are only peak moments in the transition process of the human being and these may include: the transition from school to find their first job, vocational integration, emotional dependence, relationships, building a family, procreation, and freedom in the use of spare time.

Moreover, youth is a stage that has a number of pressures: meeting family expectations, school accountability, and friends, sentimental experiences having a partner, and all type of norms or beliefs that media and peer group imposes to them [23]. Besides, youth is a stage in the life that represents social status. Being young also implies: a 
marketing theme, brand, and number of traits that society imposes. The society infringes on the youth certain features that are perfectly market it such as: fashion, esthetic, music, technological, among other elements.

The essence of being young brings benefits: the energy that this stage has, and new experiences that can be delved, are being sold [24]. The prestige and the very meaning of youth brought to market involve signs of expression for the high price and popularity, called as the "juvenilization", focused on the esthetic of body and the attempt to look younger by incorporating the appearance that characterizes youth models. Several youth signs and elements have been popularized by the mass media and social networks, which recurrently manifest the efforts to achieve legitimacy and valorization through the body. Likewise, Marguilis and Urresti [21], youthfulness can be acquired as cultural imitation and is offered as a service on the market.

Once we have described in this section youth as a category of analysis, we will discuss the elements of leisure. Through leisure, people used to be freed from all of their obligations; therefore, leisure is viewed as a liberator. Young men and women transcend from a stage where they want to experience things for different reasons despite they are not yet ready for it, and because do not have the total freedom required, as they are still dependent on their parents or guardians. This may be related to some limitations youth deal with, because they do not have the resources, the freedom to take their own decisions, or they need the parental consent. In addition, because of the lack of money they may not be able purchase of goods and services of recreation such as event tickets, entertainment venues, and drinks, among others.

Despite the multiple limitations that young people deal with, they intent to fulfill their goals, forge their identity, and socialize in the everyday life. It is to be considered a fortune to the Millennials, a person reaching young adulthood in the early 21 st century, that technology in recent decades has taken a strong impact on human beings. For instance, the increasing sociability of young people through the Internet, their social networks, and consumer practices, are the cornerstone for communication in the modern era, despite the loss of personal contact "...the online sociability does not represent a shift in other forms of belonging, but can extend the traditional circuits of meeting and socializing." [25]. Social networking is considered to be updated, fashionable, and encourages young people to seek prompt information. More and more, youth become informed consumers, learning about the market of recreation. However, as well as accessing to different sources of information can provide important benefits, they also deal with certain risks because security issues are involved.

Furthermore, studies about tourism provide data about how young people could be facing different problems or dangers carrying out their recreational activities, which relates the specific context of violence in Ciudad Juárez, because of the culture of illegality and anarchy of the criminal organizations. In this respect, a study about the recreational use of drugs in Mexico, is linked to the evolution and trends of youth leisure associated with a high consumption of alcohol, illegal drugs, and vandalizing; resulting in the emergence of social phenomena known as "the big bottle", and the proliferation of consumption of synthetic drugs [17]. 


\section{Data Mining Applications in Social Aspects}

Data Mining, is the extraction of hiding and predictable information inside great data bases, is a powerful new technology with great potential to help to the companies or organizations to focus on the most important information in their Bases of Information (Data Warehouse). Sumathi and Sivanandam [26] indicated the aim of data mining is to extract implicit, previously unknown and potentially useful (or actionable) patterns from data. Data mining consists of many up-to-date techniques such as classification (decision trees, native Bayes classifier, k-nearest neighbor and neural networks), clustering (k-means, hierarchical clustering and density-based clustering), association (onedimensional, multidimensional, multilevel association, constraint-based association). Many years of practice show that data mining is a process, and its successful application requires data preprocessing (dimensionality reduction, cleaning, noise/outlier removal), post processing (understandability, summary and presentation), good understanding of problem domains and domain expertise.

Data mining tools predict future tendencies and behaviors, allowing businesses to make proactive decisions leaded by knowledge-driven information. The automated prospective analyses offered by a product thus go beyond past events provided by retrospective typical tools of decision support systems. Data Mining tools can respond to questions of businesses that traditionally consume too much time to be solved and to which the users of this information almost are not willing to accept. These tools explore the data bases searching for hidden patterns, finding predictable information that sometimes an expert cannot find because this is outside expectations [27].

One of the most transcendental aspects of the use of Data mining is denominated Social Data Mining, which tries to find different patterns in predefined clusters in the network, like the groups of discussion, Use nets, thematic chats among others. Other work has been focused on extracting information about online conversations such as the USENET PHOAKS [28] mining messages in the USENET newsgroup that recommend Web sites. Categorizing the users mentions to create lists of popular Web sites for each group. Where? [29]. It has been analyzed the newsgroup information and the Usenet conversations and if they have been used to create visualizations of the conversations. These visualizations can be used to find conversations with the desirable characteristics, such as equality of participation or regular participants. In Fiore [30], also was extracted information of newsgroups and visualizations of the conversation subject, contributions of individual messages, and the relation among them were designed. Another research has been centered in extracting the information of web user records.

The Log files [31] register information of the users, analyze this to find common connections between Web pages, and they construct diverse visualizations of these data to help user navigation through Web sites. Persecuting the navigation metaphor, some investigators have used the term "social navigation" in order to characterize the work of this nature [32]. Finally, a different technical approach [33] uses the register of activity - e.g., a sequence of visited URLs during a session like the basic unit. Based on this, they have developed techniques to calculate similarities between the trajectories of sequences and to make recommendations - for example, to similar pages to the visited ones. 


\subsection{Social Data Mining}

The motivation to make an approach by means of applications with Data Mining is based on previous works of Social Data Mining in this research area [34]. This research area emphasizes the role of the collective analysis of conduct effort, rather that the individual one. A social tendency results from the decisions of many individuals, joined only in the location in where they choose to coexist, yet this, still it reflects a rough notion of what the researchers of the area find of what could be a correct and valid social tendency [35]. The social tendency reflects the history of the use of a collective behavior, and serves like base to characterize the behavior of future descendants [36]. The Data Mining approaches for social aspects look for analogous situations in the behavior registers [37].

The investigators look for situations where the groups of people are producing computer registers (such as documents, USENET messages, or Web sites and links to groups with a specific profile) like part of its normal activity. The potentially useful information implicit in these files is identified; and the computer techniques to display the results are designed. Thus the computer discovers and makes explicit the "social tendencies through the time" created by a particular type of community.

The systems that analyze social aspects with Data Mining do not require expert users in no new activity, due to this, the investigators in the subject try to explore the information of the user's preference implicit in the existing activity registers. There is a wide variety of applications of data mining and in various areas of study, for example: Reyes-Nava, Flores-Fuentes, Alejo, and Rendón-Lara made a investigations related to data mining of risk factors in students [38]; Rodríguez-Maya, Lara-Álvarez, May-Tzuc, and Suárez-Carranza write and evaluation of CENEVAL for students [39]; GonzalezMarron, Enciso-Gonzalez, Hernandez-Gonzalez, Gutierrez-Franco, Guizar-Barrera, and Marquez-Callejas development and modeling students' dropout in Mexican Universities [40].

\section{Context of Youths in Ciudad Juárez}

Youth must be legitimated as a social group integrated by individuals that shared ideas and values within a specific context. The context of young people in Ciudad Juárez, is permeated by social, economic, and cultural reality that has influenced violence and poverty. Ciudad Juárez has been classified as a city where the culture of illegality reigns, "abandoned for many years by different levels of government in the most important areas of social policy" [41]. According to Lourdes Almada [41], Ciudad Juárez and their families have experience processes of profound transformation due to three main factors:

a) An unprecedented population growth, constituting the city as a hub of immigration attraction: its population quadrupled between 1960 and 2000.

b) Massive incorporation of women and young people to work; for example, a difference of about $10 \%$ is observed between the participation rate of women aged 15 to 39 years in Ciudad Juarez, about the national average rate; and 
c) A policy based on urban growth, land speculation, and the great interests of construction companies, rather than the needs of families and the general population housing. (p. 68)

In the census of 2015 by The National Institute of Geography and Information (INEGI) [42], indicated that in Mexico the segment of the population aged between 15 and 29, is an important social force, economic, political, and cultural. Data shows 38.3 million young people whose average age is 27 years old, which $50.3 \%$ are women, and $49.7 \%$ men. The population in the state of Chihuahua is about 34406,465 people, but a significant $39.10 \%$ of the population is located in Ciudad Juárez, the largest city. The average age for men and women was 25 years in the municipality. There are 862,942 young people aged between 15 and 29, which $50.05 \%$ are men, and $49.95 \%$ women. The population distribution by gender is almost equals $(49.97 \%, 50.03 \%$ men and women); therefore, there is a ratio of 99.89 men per 100 women. While at the national level were $48.83 \%$ men, and $51.17 \%$ women, implying a greater number of women in compare to Ciudad Juárez.

Nowadays, Ciudad Juárez offers different types of entertainment venues for young people. There are alternatives such as variety of conventions, sporting events, music, shopping malls, clubs, casinos, bar and restaurants, as well as, some natural areas for outdoor recreation such as the Dunes of Samalayuca, an important desert area located on the margins of the municipality, among other surrounding areas. The insecurity that citizens from Ciudad Juárez has deal with, influences the choices for entertainment, as from 2008 a wave of violence was recorded, modifying the everyday life and consequently, the ways to be organized for leisure. During the most critical years of violence, 2008-2012, there were massive closures of different types of business, which was critical for entrepreneurs. However, the current offering and demand for entertainment and recreation arise, resurging the social life in Ciudad Juárez. However, the experiences from past years in relation to public insecurity have led to changes in the ways in which young people attempt to use their spare time.

\section{$7 \quad$ Methodology}

This is a descriptive and exploratory study through a survey research design. The purpose of this study is to analyze the youth organization in relation to leisure, we utilize the approach of organization as a group of people that build social relations giving meaning to the shared ideas and values [14]. The random sample consists of 300 youth from Ciudad Juárez. The sample was calculated using an online program for sample calculations of finite population, where 862,942 youth and the relational age range 1829 [42]. With a confidence level of $90 \%$ and an error of 5\%, the sample is 300 . The surveys were conducted in various public places such as parks, sports fields, shopping malls, bars, restaurants, and in educational institutions: high schools and universities, during 2017.

For data collection, it was design and validated a survey instrument designed Ramirez in 2017. The instrument was organized by items related to different dimensions, and indicators or categories of information, adapting five organizational elements 
about features that characterize the youth organization: social structure, social actors, goals, interests and choices [43]. Through the elements mentioned, help to identify demographics, planning, choices and preferences for leisure.

To ensure proper handling of data and get a better data entry, the responses from the survey were organized by utilizing in the Statistical Package for Social Sciences (SPSS version 23.0). The analysis was carried principally through descriptive statistics, frequencies and ranges of the relationship of the domains, and categories classified with based on the elements of organization adapted. The relation of the items and construction model organization are using Data Social Mining with the Software Applications of Weka 3.9.2, and Tableu 15.0.

\section{Analysis}

The analysis is realized with based on the classification adopted in order to identify the relational domains that characterize the youth organization: social structure, social actors, goals, interests and choices [43]. The domains described before, were itemize by categories that reveal youth organization on carrying out their leisure activities: demographics and family structure; choices and entertainment preferences by age, gender, and by type and frequencies of activities; the before and after-party activities, the planning process, spending, and companionship. Other categories that emerged are render, the organizational network, and the social construction of youth and leisure in a vulnerable city.

a) Youth and demographics. The demographics of youth participants in the study show results by gender, $55.33 \%$ female, and $44.67 \%$ male. Regarding the sexual preference of young people, $90.33 \%$ heterosexual, $5.67 \%$ homosexual, and $3.67 \%$ bisexual. The ranges of youth aged $15-20$, is $45.67 \%$, followed by the range of $21-25$ with $43 \%$, and $26-29$ with $11.33 \%$. The level of education of youth is related to the age grouping of participants: $70.67 \%$ of respondents have a degree from a university, the $16.33 \%$ completed high school, and $5.67 \%$ have completed middle school. The remaining, $4.67 \%$ have a technician career, and $1.33 \%$ with primary or incomplete. Also, the predominant civil status is single, with $87.67 \%$, then, $4.33 \%$ is married, and $7 \%$ in free union. Only $0.67 \%$ is divorced, and widowed $0.33 \%$. (See Figure 1). The family structure of youth is relevant because it mirrors the social structure of Ciudad Juárez. Regarding the structure of family of the young people, these have mostly $64 \%$ a traditional family i.e., in this type of family it is present the father, mother, and children. Followed by $16.67 \%$ of youth with a single parent family, mostly represented by mother and children. A minority of respondents, $9.67 \%$, has their own family, living with their partner since the marital status. The origin and time of residence are relevant in the discussion of immigration and identity. More than two thirds of young people were born in Ciudad Juárez, a significant 78.26\%. While the origin of the remaining of respondents, $21.74 \%$, were from Veracruz, Durango, and Torreon. Regarding the residence in Ciudad Juárez, $47.33 \%$ of respondents have an average of 13 to 20 years living in the city. Followed by $39 \%$ with 21 years or more, as well as, $7.33 \%$ from 6 to 12 years, $4.67 \%$ from 2 to 5 
years, and $1.67 \%$ has one year or less of residence in the city. The area of residence of youth reflects spatial information about the population. For instance, significantly, $47 \%$ is located by the south of the city $(18.67 \%$ by Las Torres, $11.33 \%$ by La Cuesta, $9.33 \%$ by Camino Real, and $9 \%$ by the Airport). As well as, $19.67 \%$ is located by the new geographical down town (12\% by PRONAF, and $7.67 \%$ from the area of Gomez Morin, a resurging area for leisure). In addition, $19.33 \%$ of the respondents live in the area located by Tierra Nueva (southwest).

b) Youth organization by choices, preferences, and planning for leisure. The frequency of youth leisure is related to the rate at which recreational activities are carried out, or repeated over a particular period of time in the given sample. The rate varies as follows, revealing the resurging social life of youth in Ciudad Juárez: $35.45 \%$, once a week; $23.75 \%$, more than twice a week; $23.06 \%$, once a month; and $17.73 \%$, every fortnight ( 2 weeks). On the one hand, young people declared being well informed about events or places for entertainment. Media and social networks play the most relevant resources used for youth about the marketing of leisure offered in the city, such as Facebook, with 70\%; followed by the $15 \%$ who are informed by direct recommendations from friends; and 5\%, informed by other means or people, such as family, different applications, and mass media both electronic and printed.

c) For the organizational resources that youth utilize, Facebook and Messenger are the most utilized networks for communication of planning leisure, $39.60 \%$ and $34.56 \%$ respectively. Followed by $11.74 \%$ who preferred using the groups of people through the WhatsApp, but $8.72 \%$ prefer to be organized by face to face communication, and $5.03 \%$ through both, phone calling, and texting. The choices for leisure varied by type of recreational or entertainment activities: $20 \%$ of youth agreed that special events (massive cultural and artistic events) is the option that they most prefer for leisure, followed by $18.33 \%$ of others that prefer other recreational events or activities. While others, $16.67 \%$ prefer the enjoyment of recreation in natural areas. Youth also choose outgoing for eat at restaurants, $14.67 \%$, and others prefer to get fun at nightclubs, $10.33 \%$. Likewise, $10.33 \%$ of youth prefer going to shopping in the city, while, $9.67 \%$ prefer going to shopping in the across neighboring town, El Paso, Texas, U.S. The choices and preferences by gender are showed in the following charts. For instance, $37 \%$ of women most likely to go to special events, instead, $27 \%$ of men have a preference for recreational events of any kind. The range of youth aged 15 to 20 have a preference for recreational events is the first place. While youth aged 21 to 25, they prefer cultural or artistic events, instead, youth aged 26 to 29 have a preference for leisure in natural areas.

d) Expectations, socializing, and networking for leisure. Leisure should be part of everyday life and its purpose bring benefits to the enjoyment and relaxing of mind, body, and spirit. Thus, findings from the survey conducted with youth shows that $13.00 \%$ aims to socialize through leisure activities, while $22.67 \%$ have the expectation of leisure as the purpose to get a recreational distraction for themselves. Other participants in the study stated that they have specific purposes on target leisure activities, as follows: $20.67 \%$ seeks going to dance; 
$18.33 \%$ for going out to eat; and $12.67 \%$ attempt to have fun by drinking alcoholic beverages. Remaining respondents stated having other purposes for leisure such relaxing, meditating, playing sports, and meeting new people. When planning to go out to have fun, the entertainment options by gender are interesting. The main objective in women is to be distracted and in the case of the most popular for men was eating. Usually, leisure serves as the bridge to build social life. Accordingly, young people attempt to carry out their leisure activities with a companionship by friends, peers from school or work, family, and their sentimental partners. The most popular option in planning leisure is with friends, $47.33 \%$, and significantly, $38.33 \%$ makes plans to going out with their sentimental partners. The reminder is represented by $11.67 \%$, who makes plan for leisure with family, while $1.33 \%$ with schoolmates and $1.34 \%$ make plans by individual choice.

e) Consumption expenditure in leisure. How much youth does is available to invest for leisure? That is an interesting question. To carry out different leisure activities, young people are available to make different expenses about: transportation, clothing, accessories, food, alcohol drinks, and ticket covers for events or entrance to specific nightclubs. Youth influences styles and design of fashion and mode. There are important expenses in which youth incurred about wearing specific styles for feeling great in the looks they love. The style of dressing fashion it depends on the kind of the leisure activity they choose but youth mostly prefer "Casual", $83.95 \%$. Others prefer to be dress up in a more formal style, $8.03 \%$. While some of the youth prefer wearing a rocker style, with $3.34 \%$. Also, $3.01 \%$ wear other styles: sporty and thematic.

In relation to the expenditures related to transportation utilized to attend the leisure activities, $44.67 \%$ of youth use their own vehicle, followed by taking an "Uber", $37.67 \%$. Also, the $6.67 \%$ uses public transportation, while only $5 \%$ used to get a ride. While $4.33 \%$ of youths is transported by the members of their family, only $1.33 \%$ venture to walk $0.33 \%$, and others use taxi services. Regarding the level of consumption in carrying out leisure activities, $69.33 \%$ of youth often spend an average of \$200.00 to \$ 500.00 Mexican pesos; followed by $20.33 \%$ in spending $\$ 501.00$ to 700.00 pesos. While in a higher level of consumption, there is $8.67 \%$ of youth spending between $\$ 701.00$ to $\$ 1000.00$ pesos, and $1.67 \%$ only spends about $\$ 1001.00$ to $\$ 1500.00$ pesos in leisure. The category that represents the higher consumption is "food", $48.33 \%$; then, the "Alcohol drinks", 32.67\%. Followed by fashion and clothing, 7.67\%, ticket covers with $7.00 \%$, and other expenses.

The relationship between the variables allows us to observe how the young people in any amount, always have their main expenses related to food and alcohol drinks, likewise, the lowest amounts (200-500 pesos) are related to own car transports and the use of uber, see figures 3 and 4.

f) Leisure and its context: security strategies and responsibilities. The context of uncertainty because the lack of public safety in Ciudad Juárez, has influenced the social life of citizens, encouraging to young people and their families to organize themselves in order to take care of their physical and emotional integrity. In addition, young people deal with fear since they have had experiences related to the violence in the city. They declared having fears to the following: 
Assaults, is the greatest fear of young people, $33.67 \%$. While others fears having a car crash, $31.67 \%$, abuse of police authority from police. Therefore, parent supervision and monitoring become a reinforced strategy as one of the security strategy for youth. In this regard, $45 \%$ of youth responded that usually they have to request permission to their parent or guardians for leisure, but $23.33 \%$ only ask for permission occasionally. Regarding the request for permission to attend "After-party", $42.86 \%$ of youths do it, but $4.84 \%$ said they do it occasionally. The fears by gender resulted to be almost similar between men and women. The designated driver is the primary responsibility among young people, especially at night, $63.67 \%$. As well as, $21.33 \%$ of youth responded that they also assign a person who is responsible for taking care or their personal belongings, such as purses and money. While $12.33 \%$ use to assign a person to be in charge of communication through the group and relatives during the activity, and $2.67 \%$, assigns someone to handle with health contingencies that youth could deal with, such as medications and further instructions for health care. Young people use to complement or extend their leisure experiences, by doing before-after parties' activities, for instance. However, two-thirds of respondents, $64.67 \%$, do not participate on the before and after leisure. Instead, only $15.33 \%$ use to carried out the before-after party, and $20.00 \%$ do it occasionally, and for these: $52.68 \%$ often go to the "After-Party" (32.21\% occasionally, and $20.47 \%$ regularly), and of these, $62.11 \%$ responded that they are normally accompanied by friends. The after party is generally carried out in places like private homes, $77.50 \%$. The set-up of different types of rules or requirements by the group of youth participating in the after-party implies that: $31.08 \%$ of youth stated, "Each person carries their consumption". Also, more than half of youth state that choosing the location for the after-party is taken with the utmost caution, 53\%. The youth responded that usually are accompanied by friends to return to their homes after leisure, $39.13 \%$. While $26.09 \%$ of youth is accompanied to return home by their partners, $22.36 \%$ use to return to their homes by themselves, and $9.94 \%$ use to be accompanied by their families.

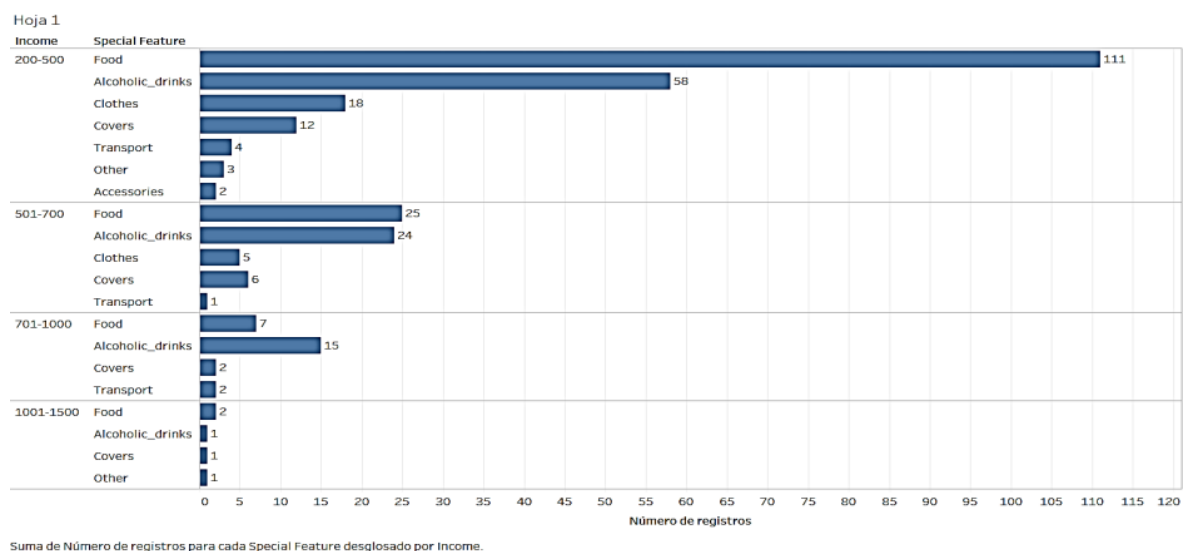

Fig. 3. Income and Special Feature. 


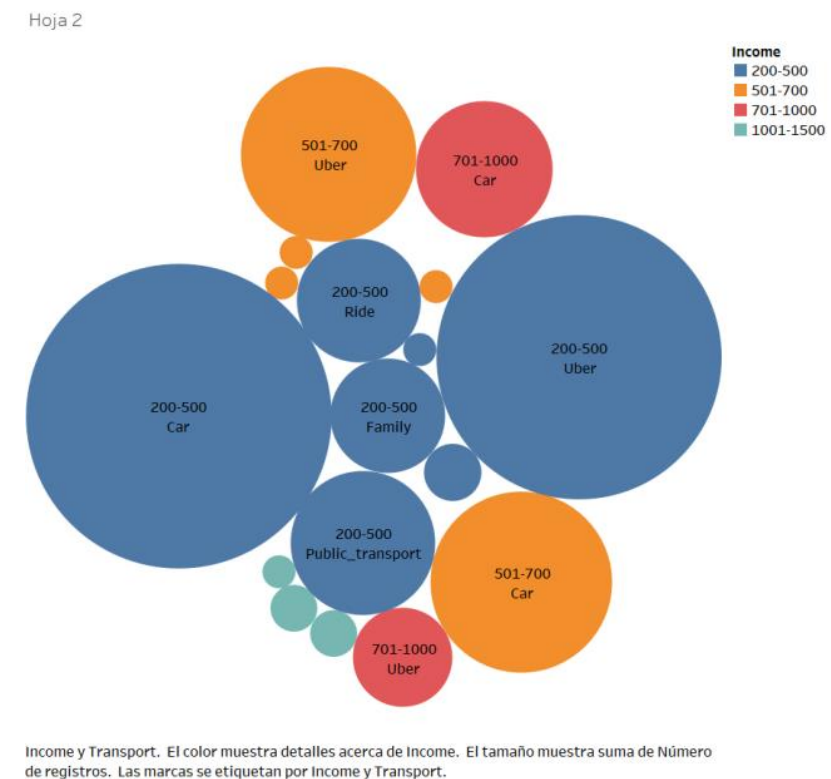

de registros, Las marcas se etiquetan por Income y Transport.

Fig. 4. Consumption expenditure in leisure.

\section{Construction Model Elements}

Model organization elements are determinate by the principal element related to Social Media on the Facebook are the most important tools to planning to go fun is related to communication with friends and family, the planning process make the construction of objectives a than the clothes, transport, spend and special feature, finally the roles and precautions, see figure 6 and the construction tree relationship items in the figure 5.

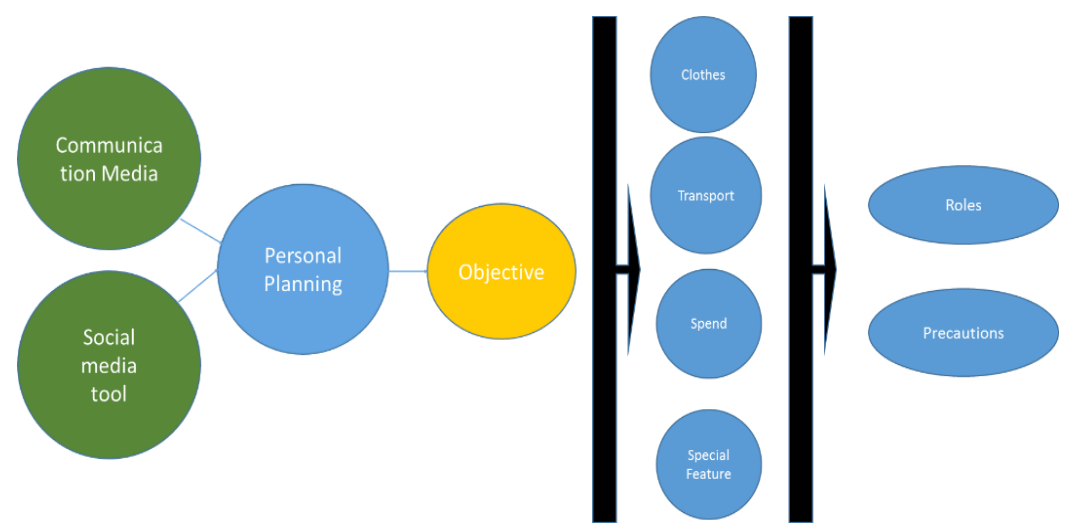

Fig. 5. Leisure Model Organizations of youth people in Ciudad Juarez. 


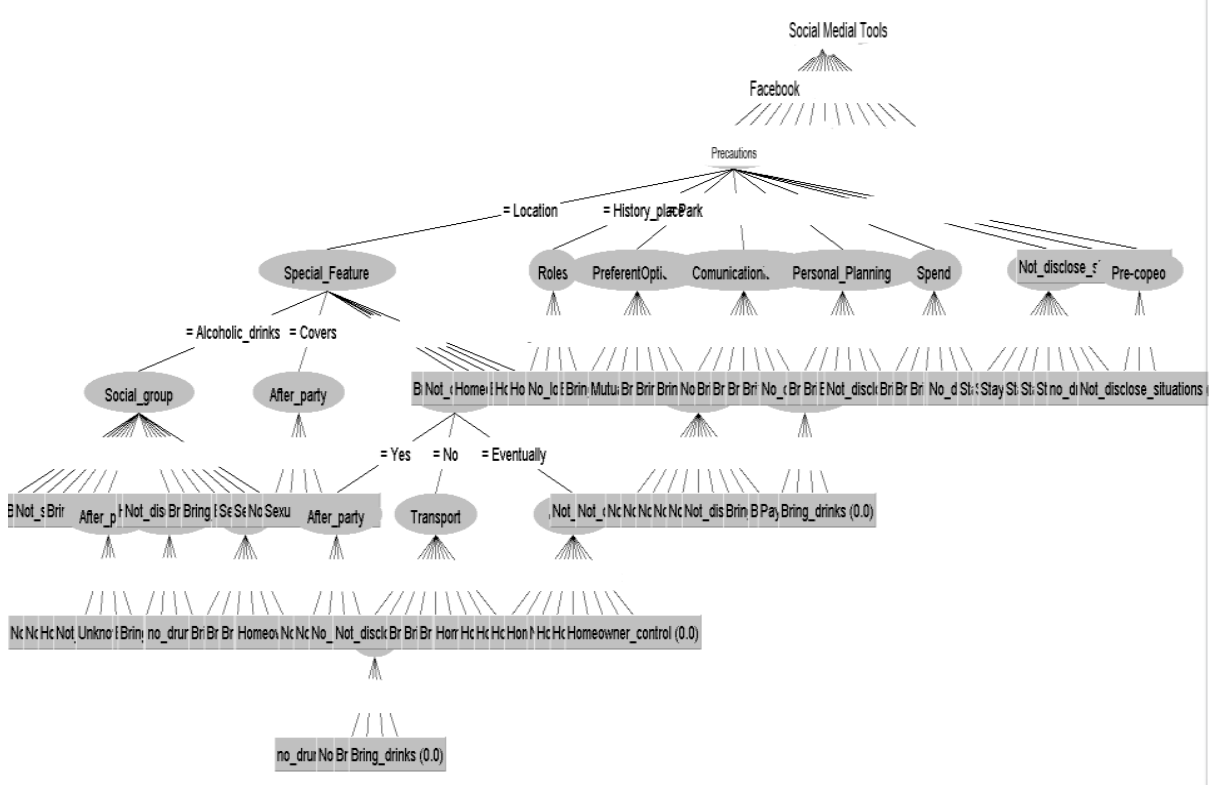

Fig. 6. Construction relation variables tree.

\section{Summary of Conclusions}

The results allow render important accounts about youth organization in fulfilling leisure. In addition to the descriptive statistics used to analyze the results from the survey conducted with youth of Ciudad Juárez, other categories emerged from the additional comments they did.

As a result of the experiences from the violence infringed in the city, young people deal with important decisions to take. For instance, beside the youth dependence from family they are tied to, accounts confirm how the adoption of different strategies is a constant in the everyday life of youth and their families. For instance, communication and companionship in leisure can be an issue of human security. In that respect, youth have to notify family or acquaintances about the places they go, with who they socialize, and the schedules.

In this regard, a female respondent indicates: "... When I go out, the most important thing I have to take care of, is that I should carry my cellular and it should be charge the battery, second, I have to inform my mother where I go". Likewise, a male youth respondent states, "I am afraid to loose communication when my battery is dead". As well as, other male respondent states this "... carrying money is important, but just the enough, in case I get mugged, I do not lose that much money"; while other young women stated that, "What it worries me the most, is to not be alone somewhere". Other male youth stated, "I'm afraid to lose my friends in the club"; also, a male youth states, 
"I fear that my car might break down when going out". Thus, youth want to keep company always in order to feel they are secure during leisure: before and after, and returning home.

Moreover, youth manifested their experiences during leisure: "Kidnappers hit me, and now I have scars". While others refer to their experiences regarding the recreational service received, "There are long lines at the clubs", "Waiters charge you more if you do not notice it, and you wait a lot for them to served you". Also, other youth participants in this study perceive that there are all types of imminent dangers that can bring more problems and risks during leisure: "The police are bullies"; "There are occasions when I spend a lot of money, especially when I get drunk "; "Taking care of my drunk friends is like babysitting".

The recurrent category of analysis emerges related to experiencing fear or dread of young people. Fear in humans is considered as a response to a natural instinct. Fear is one of the most basic emotions of humans, and is associated with anxiety, anguish, and panic. Fear can influence individuals and communities, even in complex societies [44]. Jean-Paul Sartre declared that "all men are afraid, all of them. Men who is not afraid is not normal, and that has nothing to do with courage" [45].

Although the decision-making about security strategies that people have to adopt, are presented on daily basis in large cities with high levels of insecurity, the United Nations Development Program, PNUD (2015) [46], has declared the basic conditions for achieving human security: Eliminating fear in the population and eliminate its shortcomings, since feelings of insecurity focuses more on the concerns of everyday life. In addition, PNUD states that human security should be people centered, and the life in conflict or in peace. Hence, it concerns about how people feel within society, the freedom that they have to exercise, the access to market, and to social opportunities. Human security means that people can exercise these choices safely and freely, having relatively confidence that the opportunities they have today, will not disappear completely tomorrow.

However, the options for social opportunities and freedom in the case of Ciudad Juárez, has been an issue, as this statement confirms by female members of the Civil Society Organizations (CSOs), "We don't even have the right to walk in our streets" [47]. By 2010, a young woman stated, "going out to have fun in Juárez, is like practicing an extreme sport; there are no conditions for young women to be on the streets for going to a bar or nightclub to have fun "(Idem). While the Round Table of Women of Ciudad Juárez has declared that, "... being young and being a woman in this city, put us in a double risk, there is no safe place for young females, since shootings have also happened near to universities"[48]. Moreover, parents have complained to the Mexican state about the disappearance of young women and the fear of families to live in such insecurity, “... seeing our daughters going out, without knowing if they will return, is an issue that affects to everyone, but no one will stop these" (Idem., 2018). In this regard, the civil association founded by relatives and friends of missing and murdered young women in the State of Chihuahua, "Nuestras hijas de regreso a casa" (Our daughters returning home), argued this "Because of the murders of young and poor women in Ciudad Juárez, which are documented since 1993, youth live in fear of becoming 
victims of femicide", stating that, "We can no longer go out and have fun, but we can be united to demand justice "(Idem.).

However, social life gradually has been recovering in the city by National Geographic-Mexico, [49]. Although CNN México [50], declared that social life, especially the nightlife, has been recovering from the years 2015 to 2018, stating that Ciudad Juárez is recognized worldwide as one of the most famous border cities for its nightlife, and where it can be perceiving a healthy environment in different places. In addition, the opening of different services has increased, such as restaurants and bars, and these located mainly in two areas that have emerged in the new geographical downtown, the area known as the PRONAF loop, and the Gómez Morin. In addition, Ciudad Juárez is considered an attraction for different investors because the strategic location as an international border, the dynamic movement of diverse capital, the purchasing power, and other important socio-economic variables.

Nonetheless, in fulfilling leisure into a context of uncertainty, a social construction surfaces throughout the youth organization as the collective imaginary pursuing the exercise of choices safely ad freely [8] \& [6]. Then, the recall of youth organization approach as a group of people related to the systematic arrangement of social relations, give meaning to ideas and values. But it is clear that youth and their families need to retake the beginning of the old atmosphere of night entertainment weekends that brought the fame of Ciudad Juarez fame: from the beginning of the XX century with the alcohol prohibition, until world war II, and later recognized also through the different decades by famous artists, visitors, and its population. After all, who does not remember the song "Noa Noa"?, a song from the decade of the 70's by the famous deceased singer, Juan Gabriel, whose lyrics describe a nightclub that mimicked life in Ciudad Juárez as a place "where everything is different", embracing enjoyment, happiness, and a friendly atmosphere. Such a place has been immortalized through that lovely song, whose memories resemble a great nostalgia for those years.

\section{References}

1. Sen, A.: Development as freedom. Oxford: Oxford University Press (1999)

2. Ramos Gorostiza, J.L.: La cuestión de las necesidades en el pensamiento económico. ICE, No 181, pp. 205-220 (2004)

3. Moreno Cámara, S., Palomino Moral, P.Á., Frías Osuna, A., del Pino Casado, R.: En torno al concepto de necesidad. Index de Enfermería. 24(4), 236-9. Disponible en: http://www.index-f.com/index-enfermeria/v24n4/10017.php (2015)

4. Maslow. A.H.: A Theory of Human Motivation. Originally Published in Psychological Review 50, 370-396 (1943)

5. Elizalde, A., Martí Vilar, M., Martínez Salvá, F.: Una revisión crítica del debate sobre las necesidades humanas desde el enfoque centrado en la persona. Polis. Revista Latinoamericana (2006)

6. Doyal, L., Gough, I.: La teoría de las necesidades humanas. Editorial ICARIA, España (1994) 
7. Max-Neff, M.; Elizalde, A., Hopenhayn, M.: Desarrollo a escala humana: una opción para el futuro. Development Dialogue, número especial, CEPAUR y Fundación Dag Hammarskjöld, Uppsala, 2010. Retrieved on September, from: http://habitat.aq.upm.es/deh/adeh.pdf, (2017)

8. Carosio, A.: El Género del Consumo en la Sociedad de Consumo. Revista de Estudios de Género. La ventana [en línea], III. (2008). Retrieved on September 22, 2017, from: <http://www.redalyc.org/articulo.oa?id=88411497006> ISSN 14059436

9. Locke, E.A., Latham, G.: What Should We Do About Motivation Theory? Six Recommendations. For The Twenty-first Century. Academy of Management Review 29(3), 388-403 (2004)

10. Oxford Dictionary (s/f). Leisure. Retrieved 14 November, 2017. www.rae.es.

11. Piquero, J.; Cabrero, F., Cordente, V.: Los oficios de la diversión en Roma. Espacio, tiempo y forma. Serie II, Historia antigua, $N^{\circ} 24$, pp. 363-379 (2011)

12. ATI. Estatutos de la Asociación Internacional de Trabajadores, Ginebra, 1866. (2017). Retrieved on September 13, 2017, from: https://anarquismoenpdf1.files.wordpress.com/2015/09/estatutos-de-la-asociacion-internacional-de-trabajadores-ginebra-1866-1.pdf

13. Mora, D.C.: Derecho a la diversión acervo jurídico de la UNAM. Repositorio en línea UNAM (2010)

14. Bock, P.K.: Introducción a la moderna antropología cultural. México: Fondo de cultura económica (1977)

15. Nuviala, A., Ruiz Juan, F., García Montes, M.E.: Tiempo libre, ocio y actividad física en los adolescentes. La influencia de los padres. Retos. Nuevas tendencias en Educación Física, Deporte y Recreación, 2003. Retrieved on September 17, 2017, from: file://C:/Users/hp\%20pc/AppData/Roaming/Mozilla/Firefox/Profiles/d8xc2nm2.default/zotero/storage/3RESAVXU/2282437.pdf

16. Munne, F., Codina, N.: Psicología Social del Ocio y Tiempo Libre. Madrid. (1999). Retrieved on September 17, 2017, from: https://www.researchgate.net/profile/Nuria_Codina/publication/257766145_Psicologia_Social_del_ocio_y_el_tiempo_libre/links/00b7d525d5643621e4000000/PsicologiaSocial-del-ocio-y-el-tiempo-libre.pdf.

17. Rodríguez Suárez, J., Agulló Tomás, E.: Estilos de vida, cultura, ocio y tiempo libre de los estudiantes universitarios. Psicothema. (1999). 11(2). Retrieved on October 17, 2017, from: http://digibuo.uniovi.es/dspace/handle/10651/27674.

18. Balardini, Sergio. De los jóvenes, la juventud y las políticas de juventud. Última Década. (2000) Retrieved on May 16, 2017, from: http://www.uacm.kirj.redalyc.redalyc.org/articulo.oa?id=19501301

19. Margulis, M., Urresti, M. (ed.). La construcción social de la condición de juventud. En: Cubides, H.: Viviendo a toda. Jóvenes, territorios culturales y nuevas sensibilidades (1998)

20. UNESCO. Declaración de los derechos humanos (2016)

21. Margulis, M., Ariovich, L.: La juventud es más que una palabra: ensayos sobre cultura y juventud. Editorial Biblos (1996)

22. Masjoan, J.M., Planas, J., Casal, J.: Elementos para un análisis sociológico de la transición a la vida adulta. Política y Sociedad 1(97) (1988). Retrieved may 2018. https://doi.org/10.5209/POSO.31832 
23. Londoño, Valencia, Sánchez: Asertividad, resistencia a la presión de grupo y consumo de alcohol en universitarios. Universidad Católica de Colombia ac-tacolombianadepsicología11 (2007) (1):155-162. Available from: https://www.researchgate.net/publication/28242875_Asertividad_resistencia_a_la_presion_de_grupo_y_consumo_de_alcohol_en_universitarios [accessed Sep 28 2018].

24. Lodoño Pérez, C., Valencia Lara, S.C., Sánchez. L., León, V.: Diseño del cuestionario resistencia a la presión de grupo en el consumo de alcohol (CRPG). Suma Psicológica, 2007. Retrieved on September 22, 2017, from: <http://www.redalyc.org/articulo.oa?id=134216871005> ISSN 0121-4381

25. Winocur, R.: Internet en la vida cotidiana de los jóvenes. Revista Mexicana de Sociología 68. Núm. 3 (julio-septiembre, 2006): 551-580. Universidad Autónoma de México. Instituto de Investigaciones Sociales. México, D.F.

26. Sumathi, S., Sivanandam, S.N.: Introduction to Data Mining and its Applications. Studies in Computational Intelligence book series (SCI, volume 29) (2006)

27. Azzalini, A., Scarpa, B.: Data Analysis and Data Mining (2014)

28. Terveen, L.: Using Frequency-of-Mention in Public Conversations for Social Filter-ing. Proceedings CSCW'96 (1996)

29. Viegas, F.: Chat circles. In: Proceedings of CHI'99, ACM Press, pp. 9-16 (1999)

30. Fiore, T.: Visualization Components for persistent Conversations. In: Proceedings of CHI'2001 (2001)

31. Wexelblat, P.: Footprints: History-Rich Tools for Information Foraging. In: Proceedings of CHI'99 (1999)

32. Munro, J., Höök, K.: Social Navigation of Information Space. Springer (1999)

33. Broedbeck, K.: The order of things: Activity-Centered Information Access. In: Proceedings 7thICWWW'98 (1998)

34. Bush, V.: As we may think. The Atlantic Monthly, July (1945)

35. Toriello, A., Hill, W.: Beyond Recommender Systems: Helping People Help Each Other. HCI in the new Millennium, Addison Wesley (2001)

36. Hé, Z., Milodragovich, K.: Discovering chinese descendents in Palé Island using Data Mining. CACCBR; Astana, Kazakhstán (2005)

37. Padméterakiris, A., Gyllenhaal, J., Ochoa, A.: Implementing of a Data Mining Algorithmn for discovering Greek ancestors, using simetry patterns. Central Asia CCBR (Data Mining Workshop); Astana, Kazakhstán (2005)

38. Reyes-Nava, A., Flores-Fuentes, A., Alejo, R., Rendón-Lara, E.: Minería de datos aplicada para la identificación de factores de riesgo en alumnos. Research Computer Science 139, pp. 177-189 (2017)

39. Rodríguez-Maya, N.E, Lara-Álvarez, C., May-Tzuc, O., Suárez-Carranza, B.A.: Modeling Students' Dropout in Mexican Universities. Research in Computing Science 139, pp. 163-175 (2017)

40. Gonzalez-Marron, D., Enciso-Gonzalez, A., Hernandez-Gonzalez, A.K., Gutierrez-Franco, D., Guizar-Barrera, B., Marquez-Callejas, A.: Evaluación de parámetros de encuesta de ingreso del CENEVAL para alumnos candidatos a ingresar al nivel superior, caso de estudio ITP. Research in Computing Science 139, pp. 135-147 (2017) 
41. Almada, L.: Diagnóstico sobre la realidad social, económica y cultural de los entornos locales para el diseño de intervenciones en materia de prevención y erradicación de la violencia en la región norte: el caso de Ciudad Juárez, Chihuahua. CONAVIM (2009)

42. INEGI. Censo de Población, 2015. Retrieved on November 14, from: www.inegi.gob.mx (2012) Censo comercial e industrial. Tipos de industrias. www.inegi.gob

43. Barba Álvarez, A.: Administración, teoría de la organización y estudios organizacionales: tres campos de conocimiento, tres identidades, 2013. Retrieved on February 10, 2017, from: http://zaloamati.azc.uam.mx/handle/11191/2600. Consulta: 10 febrero (2013)

44. Fuentes Gómez, J., Rosado Lugo, M.: La construcción social del miedo y la conformación de imaginarios urbanos maléficos. Iztapalapa, Revista de Ciencias Sociales y Humanidades, México, pp. 64-65 (2008)

45. Delemeau, J. (Ed.): El miedo: reflexiones sobre su dimensión social y cultural. Medellín, Colombia. Corporación Región (2002)

46. PNUD. Informe sobre Desarrollo Humano, 2015. Retrieved on January 10, 2018, from: http://hdr.undp.org/sites/default/files/2015_human_development_report_overview_-_es.pdf

47. CIMAC, Cimacnoticias. 2010. Retrieves 10 sep 2017. From https://www.cimac.org.mx/node/5

48. NUESTRAS HIJAS DE REGRESO A CASA, A.C., Quienes somos, 2018. Retrieved on Febrero 06, 2018, from: https://nuestrashijasderegresoacasa.blogspot.mx/p/quienes-somos.html

49. National Geographic-Mexico. The resurging of social life in Ciudad Juarez. (2017). Retrieved on January 13, 2018, from: https://www.nationalgeographic.com/.../juarez-mexico-border-city-drug-cartels-murder.

50. Wordpress. Vida nocturna en Ciudad Juárez, 2018. Retrieved on January 06, from: https://vidanocturnajuarez.wordpress.com/ 